\title{
ARTEFACT COLLECTING: CREATING OR DESTROYING THE ARCHAEOLOGICAL RECORD?
}

\section{ZBIERANIE ARTEFAKTÓW: TWORZENIE CZY NISZCZENIE ŹRÓDłA ARCHEOLOGICZNEGO?}

\author{
Paul M. Barford \\ https://orcid.org/0000-0003-3903-2977 \\ Independent Researcher \\ http://paul-barford.blogspot.com/
}

\begin{abstract}
This paper examines some of the arguments used by archaeologists in favour of collaborating with artefact hunters and collectors who claim that these activities produce information that is useful for archaeological research and is a form of public engagement with archaeology. It takes as a case study records of 48600 medieval artefacts removed from archaeological contexts by artefact hunters and recorded by the Portable Antiquities Scheme in England and Wales. The past and potential uses of these records as an archaeological source are objectively reviewed, together with an assessment of the degree to which they provide mitigation of the damage caused to the otherwise unthreatened archaeological record. It is concluded that, although information can be obtained by studying records of findspots of addressed artefacts such as coins, in general the claims made in support of professional archaeological collaboration with this kind of activity prove to be false.
\end{abstract}

KEYWORDS: artefact collecting, creating archaeological record, destroying archaeological record, archaeological context

In western Europe and North America, there are two main approaches to the practice of hunting for and collecting of archaeological and historical artefacts. In most areas, it is condemned and restricted because it is seen as destructive to the archaeological record (Elia, 1997; Temińo, Valdés, 2015). In several other regions, in certain circles of the USA, England and Wales, Scotland, Belgium (Flanders), The Netherlands, Denmark, Norway and Finland, there is a liberal approach to artefact collecting by members of the public. There it is seen as a meaningful social practice, a means 
allowing the public to engage with the past, a form of "archaeology for all" (Hart, Chilton, 2014; Dobat et al., 2020). These differences in approach are embedded in the legislation and also the public dialogue between archaeology and the general public in these two regions.

It is nevertheless incontestable that the growth of popularity of the collecting of portable antiquities (together with the artefact hunting that supports it) is one of the main agents leading to the destruction of the archaeological record all over the world. In many regions, sites are being selectively exploited as a source of collectables both for private collection and fuelling the expanding online market. In many regions of the USA, there are probably very few Native American sites that have not already been cherry-picked by collectors of lithic artefacts, while in parts of the Saharan North Africa and Australia (Lever, 2016; Barford, 2020), many sites have been completely collected away, in the latter case literally by the lorryload. This destruction is ongoing, the advent of the metal detector made artefact pickup much easier and deeper-reaching than eyes-only recovery. As a result, hundreds of thousands of artefacts (including coins) are each year openly passing through sites like eBay, hinting at massive scales of depletion of the archaeological record.

On eBay in the first week of January 2020, the search engine reveals that in that week, in the section of the portal dedicated to antiquities, there were just over 72000 antiquities (and "antiquities"), mostly small objects of metal, being sold in just that week alone ${ }^{1}$. More artefacts and pseudo-artefacts appear in the "collectables" section (under "cultures and ethnicities"), here for example were a large number of Native American lithic items (19 520). In the numismatic section, there were 104800 ancient and medieval coins on sale (plus several thousand other examples from SE Asia and the Far East). This means that in total, there were at least 23000 metal artefacts plus over 105000 coins and a total of 20611 prehistoric lithic artefacts being offered for sale at the beginning of January. About 21000 of the total number sold in that week, a rate that (since most were 7-10 day auctions) could imply that the total number of these objects currently being sold annually would be over 800000 objects.

The number of collectors this represents is unclear. Latest estimates suggest that in England and Wales there are 27000 active artefact hunters with metal detectors (Hardy, 2017). In the US, it was said that a decade ago there were 50000 collectors of ancient coins, and perhaps no less than a 100000 worldwide (Coin Community Forum, 2015), all eager to expand their collections with freshly-surfaced material. There are thousands of collectors of arrowheads and Native American artefacts, and large numbers of collectors of objects from the classical world, ancient Egypt and Biblical artefacts.

Public perceptions of how the past is studied have been affected by the prevalence of artefact collecting and literature (Vernet, Le Quellec, 2017; Greenlight, 2020) or

${ }^{1}$ While many of these dealers were based in the USA and western Europe, over 12120 of these artefacts were British, prehistoric, Roman and Anglo-Saxon artefacts (plus some 6400 Celtic and Roman coins, also 204 early medieval and 2036 medieval coins) being sold by dealers based in the UK. 
copious internet resources related to it. There is an incessant stream of favourable media coverage, with frequent newspaper stories relating how an amateur with a metal detector has made discoveries that have excited professionals (and in the process sometimes received a hefty reward). In the public imagination, archaeology is becoming disassociated from altruistic academic enquiry and becoming increasingly seen as just another area where the consumer society finds fulfilment. Public opinion about archaeology is being contaminated by ideas that it is merely a treasure hunt "digging up old things" and ordering them in collections. In future, archaeologists may find themselves having problems getting funding for large and detailed projects when general opinion is that all that is really needed to do useful archaeology is a metal detector and a spade.

\section{ARCHAEOLOGICAL COLLABORATION WITH ARTEFACT HUNTERS}

In the countries with a liberal approach, many heritage professionals support the rights of collectors of portable antiquities. There is a strong lobby of archaeologists who not only seem unconcerned about the erosion of the accessible archaeological record due to activities like "metal detecting", but who profess the view that collection-driven exploitation of the archaeological record is a legitimate form of public engagement with the past (Deckers et al., 2018; Dobat et al., 2020). These archaeologists argue that, when done in what they call "a responsible way" (sic!), amateur artefact hunting and collecting are, in effect, beneficial and "archaeology and society at large are best served by cooperating with hobby metal detecting" (Dobat et al., 2020, p. 14). Artefact hunters engaging in collection-driven exploitation of the archaeological record with metal detectors have even been labelled "citizen archaeologists" (Boulton, 2016) by the academics craving access to the objects they find. Winkley (2016, p. 13) has suggested that artefact hunters have ,a significant contribution to make towards a more complete understanding of the $[\ldots]$ landscape".

In the view of archaeologists in countries that liase with them, the material artefact hunters find can be recorded and documented and thus, "advance archaeological knowledge, complementing traditional archaeological survey and fieldwork" (Deckers et al., 2018, p. 324). The focus is therefore on maintaining good relations with the exploitive artefact hunting and collecting community so that they continue to discover and show new and interesting loose objects for study.

Such object-centred attitudes began to take over the public debate in some parts of Europe from the end of the 1990s. Later, similar arguments in favour of collaboration with artefact hunters and collectors were also being proposed in the USA (e.g. Pitblado, 2014, Pitblado, Shott, 2015; Reeves, 2015). This led to a paradoxical situation when in the aftermath of the US-led invasions of Afghanistan and then Iraq, western media expressed moral outrage about the looting of sites by brown-skinned natives in the occupied countries, while at the same time treating as a godsend for archaeolo- 
gists white Europeans with their metal detectors doing exactly the same thing at home (Kennedy, 2007). Scholars (e.g., Thomas, 2016, p. 141-142) consider "hobby metal detecting" (collection-driven exploitation of the archaeological record) as absolutely unrelated to archaeological looting (represented by them as solely a commercial activity). In fact, whether money is involved or not, the archaeological effects are the same.

As a result of their constant and uncritical praise of artefact hunting and the alleged benefits it has brought to the discipline, archaeologists advocating collaboration with collectors are unwittingly involved in promotion of the hobby. They also tend to dismiss offhand, sometimes in a hostile manner, the concerns and questions raised by others urging that archaeologists should be collaborating with each other in the protection of the archaeological resource from this kind of unsustainable exploitation. Supporters of collecting retort that it is a "simplistic and incorrect basic assumption" to consider artefact hunting and collecting damaging (Deckers et al., 2018, p. 323-324; Karl, 2019). They consider that no cultural damage occurs unless artefacts are removed by digging into stratified contexts or the recovered artefact itself is irretrievably lost, together with the information about it. The argument that the removal of artefacts from surface sites does little damage (Dobat et al., 2020, p. 10) is based on a narrow view of the discipline that its identity is defined by excavations and discoveries and the assumption that excavation is the only methodology by which archaeology is done.

Claims in such circles that artefact hunters are allies, with "common interests" with archaeology imply that the primary aim of the latter discipline is merely digging up old things. Deckers et al. (2018, p. 324) suggest

it is too simplistic to equate unreported metal-detected finds with the loss of cultural heritage, $[\ldots]$ unreported finds are not damage, but at worst a zero-gain (as they may not have been picked up by regulated fieldwork).

Another object-centred view is that there is little "likelihood that an artefact would yield information if it was not recovered by" an artefact hunter (Deckers et al., 2018, p. 324; Bland, 2005, p. 446-447; Thomas, 2008, p. 7), the loss of information when they are removed from their archaeological context is ignored, and is excused by representing the loose artefacts in private collections as somehow saved from having been "lost".

The archaeological supporters of private collection-driven exploitation of the archaeological record therefore participate in the representation of collecting as a form of artefact-rescue. In their manifestos we find passages that suggest that artefacts are susceptible to plough damage and artificial and natural corrosion processes:

In the open and intensely cultivated landscapes of Europe, not only are the metal finds in the ploughsoil in danger of getting lost [...] detector finds $[\ldots]$ are currently threatened by increasing deterioration in open and cultivated landscapes, their extraction from the ploughsoil might be the best option for the find to be recorded, preserved, and made accessible. (Dobat et al., 2020, p. 9-10; see Bland, 2005, p. 446-447) 
These arguments however fail to take into account that although artefacts are undoubtedly damaged to varying degrees in different soils and under diverse agricultural regimes in various areas of Europe, the extreme effects that are claimed to be universal are in fact localised and dependent on several factors (see also the discussion by Christiansen, 2016, p. 26-28). In the online antiquities sales, many thousands of artefacts are offered day after day and week after week that are rejected by artefact hunters as not being good enough for their own private collections. Yet the state of the majority of them (and those recorded with photographs in databases of metal detector finds) shows us that most do not come from damaging environments. Their patina is intact, there are few fresh breaks, and they retain their values as collectable items because of that. The same more often than not applies to artefacts recovered en masse and recorded during commercial artefact hunting rallies or archaeological surveys. This argument is to a large extent special pleading, and it is disturbing that archaeologists speak with one voice with collectors and dealers in uncritically using it in the public domain.

In support of archaeological collaboration with artefact hunters engaged in collection-driven exploitation of the archaeological resource, attention is frequently drawn to a number of pieces of recent research based on material obtained by such collaboration that supports the belief that "detector finds can be analysed as scientific data" (Dobat et al., 2020, p. 7-9). The work that is presented to uphold this view is, however, mostly object-centric, and often loses sight of the methodology that separates archaeology from mere random artefact hunting and artefactology. The studies mostly concern decontextualised late prehistoric, Roman or Early Medieval metal artefacts of an emblemic, or even addressed nature (that is objects that were created with the intention of bearing information, such as finds that bear a text or iconographic information). The methods applied are rather unsophisticated: typological classification, plotting distribution maps of specific artefact types or associating finds with events or groups known from written sources. This includes ascribing ethnic identities to the owners of the ancient objects on the basis of their ornament. These are all methods that would have been familiar to Gustav Kossinna more than a century ago (Barford, 2016). It is difficult to account for such a low level of methodological awareness of the archaeologists adopting such an approach.

This paper will attempt to examine the idea that material gathered and reported by artefact hunters can provide a source of information for modern archaeological research. To what extent are the claims of the archaeologists cited above tenable? This contribution is presented in a collection of papers offered to Professor Tabaczyński, and one of the most notable characteristics of much of his life's work was the attention he paid to questions concerning the epistemology of archaeological sources/evidence. Over three decades ago, he had adopted a consciously theoretical approach to medieval archaeology (Tabaczyński, 1987), and had long been engaged in research on the early Polish state, contextual study of medieval numismatic material and the study of deserted medieval villages in France. It therefore seems appropriate to take as a case study in a paper dedicated to him the topic of the research value of medieval material 
removed from the archaeological record by artefact hunters and collectors and then recorded by archaeologists in one of the countries with a liberal approach to artefact hunting. The best documented example is offered by the database of the so-called Portable Antiquities Scheme (PAS) of England and Wales (Bland, 2005). The case study will cover records referring to the artefactual evidence of the tenth century and High Middle Ages in England and Wales (900-1300) as recorded by the PAS.

\section{A CASE STUDY: THE HIGH MIDDLE AGES IN ENGLAND AND WALES}

In England and Wales, the discipline of medieval archaeology developed relatively recently and is one of the fastest-growing fields in archaeology today. Scholars working in this area have long struggled with notions connected with the archaeological source. In particular this has concerned freeing themselves from the tyranny of the written record (Champion, 1991) and the notion that archaeology was not the "handmaiden to history", tasked with providing artefacts to be merely as illustrations of phenomena and events known through from written records. To reduce the field of material culture in this way runs the risk of compromising the mutuality of the partnership with the historical approach (Pesez, 1990) but also the idea that the archaeological evidence through the application of the archaeological methodology is a source of information in its own right. Analysis of the archaeological evidence and material culture may enrich or call into question written evidence. The relationship of medieval archaeology to social anthropology, research into landscape geography and other fields of study, take the discipline beyond the study of physical remains alone. The rich medieval archaeological database has been used to address a range of important theoretical concerns in contemporary archaeology, such as questions of gender, agency, and power (Gilchrist, 2009). As a result, medieval archaeology is playing an increasingly important role in archaeological thinking throughout the world and undeniably can aspire to become one of the nodal points of methodological and conceptual exchanges within the social sciences. To what extent can the material recovered by artefact hunters be used to address these more sophisticated questions?

The Portable Antiquities Scheme (PAS) was set up in 1997 to encourage the reporting of artefacts - especially those that did not fall under the legal category of "Treasure" (defined by the 1996 Treasure Act) found by members of the public in England and Wales (Scotland and Northern Ireland have a different system). The core aim was "to minimise the loss to our heritage caused by the failure to record systematically objects found by the public[,] metal-detector users, amateur field-walkers and chance finders". The aim was to create a resource that could be used for research at many different levels (Worrell et al., 2010). The majority of this material recorded over the past 23 years has been found by artefact hunters. Although there are now probably well over 20000 active metal detectorists in England and Wales (Hardy, 2017), precise figures on the scale of clandestine activity are lacking. The latest estimates (Barford, 2019) suggest that only 
one in eight $(12,5 \%)$ finds made by artefact hunters with metal detectors in this area have, in fact, resulted in a record in the PAS database ${ }^{2}$.

In the middle of March 2020, the PAS database (Portable Antiquities Scheme, 1996-2020) contained 949687 records (containing information about 1487195 objects). Of these, according to the database's search engine, 48604 records (referring to 60160 artefacts) dated to between $900-1300^{3}$. This means that slightly less than a half of the entire body of data consists of records of material of the tenth century and High Middle Ages.

The material comes from all over the country (fig. 1), but only from specific types of landscape. Most reported finds come from lowland sites, slightly less than 2\%

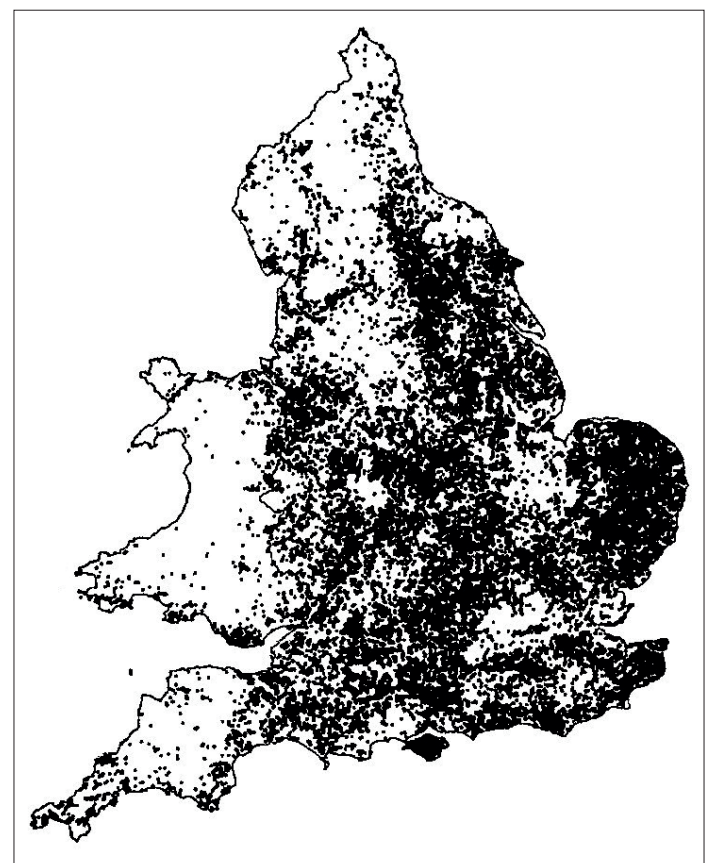

Fig. 1. Map of medieval finds recorded by the PAS (after map fig. 1 by E. Oksanen in Lewis 2018, lack of scale and north point in original)

2 Figures previously established by the writer indicate that by mid March 2020, Hardy's estimated c. 27000 detectorists would have found c. 8,033,032 recordable artefacts (or their groups) since the PAS began.

${ }^{3}$ https://finds.org.uk/database/search/results/fromdate/\%2B900/todate/\%2B1300/show/100. Frustratingly, the search facility of the PAS database is not very reliable or stable, it tends to give different answers when a search is repeated even on the same day, and the totals do not always match. There are also inconsistencies and errors in some records that also produce false results. All quoted statistics come from a search conducted 8th March 2020. https://finds.org.uk/database/search/results/fromdate/\%2B900/ todate/\%2B1300/show/100/objectType/COIN 
were from sites above $200 \mathrm{~m}$, and only $0,3 \%$ above $300 \mathrm{~m}$ a.s.l. (Robbins, 2014, p. 41, fig. 6). Ease of access to the land is an important factor in determining which areas are exploited by artefact hunters more intensively. It has been known for some time that there is a clear concentration of searched areas near to major roads or in the vicinity of habitation areas such as towns (Richards, et al., 2009, 2.4.2.1, Kershaw, 2013, p. 13-14). Where we have records of land use of material recorded by the PAS, some $87 \%$ of the material comes from cultivated land (ploughed soil is easier to dig to extract finds). The material that is reported is far less frequently collected from what is now grassland, heathland and woodland (this comprises about $4 \%$ of the PAS database entries), waterways, wetland and coasts also account for less than $2 \%$. Very little of it comes from open areas in towns and cities or around monumental high status sites such as castles (many of which are protected areas where artefact hunting is forbidden). The finds in the PAS database can thus provide little information on topics related to urban centres and elite sites.

Even in the rural setting, the scope of searching is limited by other factors, not least the continuity between Medieval and modern landscapes over much of England and Wales. While Britain has a large number of villages (c. 3000) that, together with the earthworks of their field systems, were abandoned between the 13th and late 15th centuries (Beresford, 1954) there are many thousands of rural settlements of medieval origin that are still occupied. Most of the area within them is inaccessible to artefact hunting, though can be investigated by supervised amateurs using archaeological methods in test-pitting (Lewis, 2007). Evidence is lacking on whether the archaeological evidence from "failed" settlement differs, and if so in what way from those of the landscapes that prospered.

The composition of this body of information is interesting, and reflects what the artefact hunters searching the sites thought was worth picking up to add to their collections, and then thought worthy of recording. At least 32770 (67\%) of the 48600 records of medieval finds were of single-finds of coins ${ }^{4}$, while a further 95 records $(0,2 \%)$ referred to coin hoards (total number of 7991 coins) $)^{5}$. There were also a further 51 jettons and tokens. The database therefore currently contains records of 40761 coins. Another numerous category were inscribed seal matrices (1524 examples). This means that, apart from coins and seal matrices, in this database, the entire High Middle Ages period is currently represented by just 14211 records of other artefacts. The bulk of them (13 555 items) may be categorised as follows: Personal ornament, 6253 items; Weapons and harness, 4922 (mostly stirrups and decorative harness fittings); Pottery fragments/sherds (records), 908; Keys and casket/box fittings, 481; Tools and production, 229 (mostly spindle whorls); Commerce, 195 (mostly weights for pan scales); Domestic implements and furniture, 143; Metal vessel and contain-

\footnotetext{
${ }^{4}$ https://finds.org.uk/database/search/results/fromdate/\%2B900/todate/\%2B1300/show/100/objectType/COIN

${ }^{5}$ https://finds.org.uk/database/search/results/objecttype/COIN+HOARD/fromdate/\%2B900/todate $/ \% 2 \mathrm{~B} 1300$
} 
er fragments, 49; Architectural, 42 (tile fragments, nails, stone mouldings); Knives, 22 examples; Lighting, 13 (lamps, lamp and candle holders). Other finds included: 86 bells, 60 book fittings, 45 dog (?) leash swivels ${ }^{6}, 42$ figurines, 36 ampullas and 8 pilgrimage badges, 19 gaming pieces. There were 658 other miscellaneous and unidentified items.

Because this material was largely found by artefact hunters with metal detectors, it is not surprising that the composition of the whole assemblage of artefacts was skewed towards metals. According to the PAS search engine, over 33070 and 11850 were of silver and copper alloys respectively (the former were mostly coins). Another 1730 were of lead alloys and 173 of gold. There were, however, only 86 iron items included in the corpus. There were also 962 ceramic items, 13 of stone, three of glass, and 10 of bone or antler. There were only six items labelled "animal remains".

There are many problems involved in using this corpus of material as a database for the study of the archaeology of the period 900-1300, even if we accept that the vast majority of this material relates to rural spheres of life only. Above all, the main problem is that it is mostly without any close context, individual items have been plucked out of a scatter of material. While the actual findspot may be known with some accuracy, the relationship of a single object with others from the same site or assemblage or with other material not collected (such as a broader pottery, slag, tile or fired clay scatter) is unknown. There is no field to record such information in the PAS database even if it was collected on site. The database records that in nearly 50000 places all over the country, archaeological material has been removed from a medieval archaeological site or assemblage, but without providing any additional information about the context of discovery or deposition.

\section{RESEARCH POTENTIAL}

In 2007, PAS marked its tenth anniversary by holding a conference at which speakers, both from within the Scheme and outside, gave a series of papers that attempted to demonstrate the research potential of recording finds of archaeological objects made by members of the public. The publication A Decade of Discovery (Worrell et al., 2010) contains 19 contributions, most of them present research on the Roman and Early medieval periods, only three consider artefact types of the High Middle Ages (Mace-heads, medieval pilgrim trinkets, seals).

The PAS website (Portable Antiquities Scheme, 2003-2020) lists examples known to the Scheme of the use of PAS data by academic and other researchers who have registered for access to the data over the past 23 years. Out of the 751 projects listed there, only 34 concern data specifically referring to the period covered here. It seems medievalists, both in Britain and beyond, see these data of very limited use to

\footnotetext{
${ }^{6}$ These copper alloy swivels from leashes (for dogs?) are unevenly represented. The database contains 45 examples, all but six of them from Norfolk.
} 
their work. The largest group (15 projects) are regional studies, sometimes merely local history projects, though seven of them seem to be more methodically sophisticated landscape archaeology projects. Another three concern identifying the scatter of material in a wider area around certain complexes or sites (monastery, town), while two are investigating medieval battlefields. Although the website records who had gained access to PAS data, not all of them had found it usable in their work. In one landscape project (looking at coastal and landuse change), PAS data were not presented at all. In another project, a foreign researcher wrote that he wanted to try to use PAS data to follow processes of medieval village formation and "evaluate the research potential of the PAS database to approach questions of shifting settlement location". In the end, access to the raw data revealed that the recorded material was not usable for such research and the project was abandoned (R. Schreg pers. comm.).

Even in regions where there are relatively dense concentrations of material taken from a microregion by one or more finders, the selectivity of types of material collected means that knowledge of the findspots cannot be used to infer much about landscape development, or zonation of activities. The poor representation of pottery in the corpus and lack of detailed records of the location, composition, extent or density of pottery and building material scatters is a major hindrance. Not only would this missing evidence provide information on settlement organization, chronology and shift, but also for determining basic features connected with past landuse (Cf. Jones, 2004, 2011). Britain's artefact hunters are rarely engaging in the sort of systematic field survey that would recover this sort of evidence.

One of the more ambitious projects attempting to use PAS data for a regional study was the study Placing Medieval Markets in their Landscape Context through PAS Data initiated in May 2015. This text-driven project (Oksanen, Lewis, 2015, 2016) attempted to analyse PAS-recorded data associated with medieval market sites and travel routes known from documentary sources, and used them to "illustrate historical economic activity" (Oksanen, Lewis, 2015, p. 58). The investigators used GIS-generated statistical tables to come up with some rather unsurprising results. They demonstrated that there is an apparent correlation between the PAS finds distribution and former commercial sites, with just over 19 per cent of all medieval objects being found within approximately $1 \mathrm{~km}$ of a known market (Oksanen, Lewis, 2015 , p. 54). This is however simply a function of the way artefact hunters focus their searches in the vicinity of known areas of past activity to find "productive" search areas. One stated aim of the project was to "create a methodology for constructing object profiles for medieval market sites, which could then be applied to identify previously unknown sites", this seems to have been unsuccessful, although the researchers identified differences between finds assemblages at these central sites and those peripheral to them. They report that certain artefact types (pilgrim and other badges, white metal trinket jewellery, floor tiles, cloth seals and tokens) occurred more frequently on or in the vicinity of known commercial centres (Oksanen, Lewis, 2015, p. 57, fig. 3). The authors present as a case study the area of Wisbech and the episcopal town of Kings Lynn. The geography and history of the trade routes through these two centres have 
been well known from the documents for over a century, and despite the claims made, it must be said that the PAS data presented in the report do not seem to add anything much to what we already know. In fact it seems that to a large extent what was known about the settlement history of the area was the driver of the search activities of the artefact hunters who later reported the selection of finds used in the study. The researchers ignore the methodological limitations relating to the fact that the generation of information is dependent on the research questions asked. Artefact hunting can only produce information on the process of artefact hunting in the modern landscape, and the only answers that loose finds deriving from it will produce for researchers relate to that, rather than to current research needs that attempt to go beyond that agenda. Rather that demonstrating that the loose information contained in the PAS database constitute a first class source of archaeological data comparable to any other (such as systematic field survey), this project creates the impression that an attempt has been made to find a means by which can be used at all.

One major problem is that if an artefact hunter comes to an archaeologist to report a find or finds, the record can only contain second-hand information about the context and associations. Very often there is no certainty whether isolated objects were part of the surface scatter that represents a site, or whether they were some kind of offsite finds. Geake (2011) has discussed the perceived difference between the two. According to her, rural accidental losses tend to be: smaller rather than larger objects, portable, easily carried objects such as coins, dress accessories or horse-harness fittings and of relatively high intrinsic worth, and they are found "more in fields than in settlements". She does not explain how the latter is determined in the case of single (for example, metal) items taken to a distant recorder, when it is the pattern of surface scatter of all types of archaeological material that should define where settlement sites are. What this model is describing however is not so much medieval behaviour, but again the selectivity of the modern collecting activity that this record is associated with. This selectivity of pickup is different from (and very much more individualised than) the more systematic and holistic retrieval regimes of archaeological investigation.

In the Guide [to PAS data] for Researchers (Robbins, 2014), while some attention is paid to site formation processes from the point of view of sampling bias (2014, p. 23-36), only on two pages at the end is the question considered whether reported metal detector finds can be used to study sites (2014, p. 72-73). Even when the locations of collected items are known in great detail, this information may have little real meaning. As Robbins (2014, p. 72) points out, "different collectors will have different patterns of activity within a site, which will affect the resulting distribution of finds". There is an interesting case study discussed (Robbins, 2014, p. 72-74, fig. 30) where a large field at Eades farm, Newbridge, Isle of Wight had been searched by an individual detectorist (2002-2010), but also separately by members of the Isle of Wight Detecting Group (2004-2010). The finds from both were plotted by GPS. The two plots (fig. 2) are completely different, showing that neither can be relied on to give a picture of the actual distribution of finds across the field. The conclusion is 


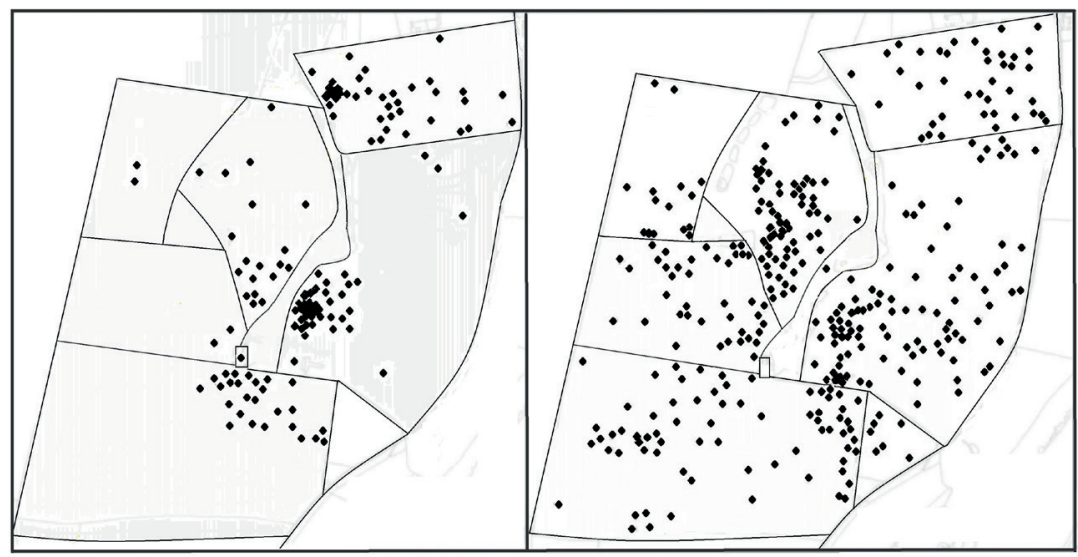

Fig. 2. Plots of co-ordinates of metal detected finds carried out in the same fields by two different parties (after Robbins 2014, fig. 30, lack of scale and north point in original)

that "without knowledge of the spatial extent and intensity of searching within a field [...], it cannot be assumed that the distribution of the recorded findspots is truly representative". In a passage at the end of the text, Robbins (2014, p. 77) also notes another aspect that affects the degree to which artefact hunting can allow characterisation of a site on the basis of the material submitted for recording:

Another factor to consider that has not been particularly touched on in this guide is the level of discrimination being used by collectors, in particular the amount of sorting of artefacts happening prior to the reporting of finds to the PAS, for example many metal detectorists do not collect non-metal objects or iron objects, and some will target particular types of periods of artefact.

In other words, in this kind of collection-driven exploitation of the archaeological record, evidence is removed from a site in a manner that cannot provide any information about it.

Tacit recognition of this fact is probably the reason why supporters of artefact hunting attempt to highlight the "big data" aspects of the material gathered in collaboration with the activity. Most of the PAS-sponsored Guide for Researchers discusses the creation and use of dot distribution maps on a broad regional or national scale (Robbins, 2014, p. 37-72, 74-77).

The other main area where PAS data are used by researchers are in material culture studies. A typical example of this is a "show and tell"-type book by the Scheme's director (Lewis, 2018) where narrativisations of a selected number of loose objects from PAS records are used merely to illustrate what we know from the written record. Many medieval finds are also presented in the PAS' recent flagship publication (Leahy, Lewis, 2018) that has a similar character. There are 13 research projects currently listed on the PAS website (Portable Antiquities Scheme, 2003-2020) that look 
at individual artefact types. Two are on dress accessories, one on jewellery, two on ampulae, and two on pilgrim badges. There is a project on pan scale weights, one on the typology of medieval arrowheads and another on seal matrices. The subjects of the other three were medieval material culture in general. One such project, Living Standards and Material Culture in English Rural Households 1300-1600 attempts to amalgamate the written evidence with the physical evidence from excavations. At the beginning, it was announced that the three-year project would also be integrating the excavated evidence with information from the PAS database, but "this dataset is not without its own problems, and as a part of the project we will be developing new methods for working with this data to exploit the value of these finds" (Jervis, 2017). Three years later, it remains unclear to what extent those issues were resolved before the project ended in November 2019.

A major issue is that the record of a selection of artefact-hunted items cannot be representative of what the archaeological record contains. As seems clear, the PAS is only a record of modern collecting habits and documents only the kinds of objects that caught the eye and interest of the collector. Thus both lost coins and seal matrices are relatively uncommon finds as both excavated and fieldwalked items, but pottery, tile fragments and iron nails occur in massive quantities on medieval sites over much of the region. Yet the PAS records suggest something else. It is notable that there are no agricultural tools represented, even though the economy of the period over a lot of the area was predominantly agrarian. While much of the grain would have been turned to flour in (wind and water-powered) mills, many households also had querns. Yet the PAS corpus contains only two examples, one of sandstone, the other a fragment of Niedermendig lava. Another five loose lava quernstone fragments from SE England in the PAS records are undated.

Recent work on Alpine ice cores has chronicled fluctuations of lead in the air and dust captured in them in the 12th century, deriving from intensification of lead mining and smelting in the Peak District and in Cumbria in Britain (Lovelock et al., 2020). While we have physical evidence from the ice cores and the written tax records of lead and silver production in England, the PAS database contains very few of the items made from this lead, because objects made from lead alloys are not considered particularly collectable by artefact hunters. Not only therefore are the types of uses this lead is being put to irretrievable through PAS records, but should a future programme of isotope studies be proposed, the material retrieved from across the country by 27000 metal detectorists is inaccessible, as many of these finds have already been discarded by the finders.

As noted above, the PAS corpus contains a disproportionate quantity of information on coins (Kelleher, 2011), with over 40000 in total from the period 900-1300 on the database, this is a large enough sample to be a valid test case to examine what information has been obtained by their recording. Although a corpus containing details of such a number of items provides more examples for numismatists to study various aspects such as typology, iconography, epigraphy, weight standards, and wear indicating circulation, so does the antiquities market. At the time of writing, 2036 British 
hammered coins were on sale by British dealers on eBay UK; none listed is noted as having been PAS reported ${ }^{7}$. Before the PAS records were compiled, there was already quite a lot of information on medieval coin use known from earlier finds.

Hoards had been fairly frequently found in the past during agricultural work and earthmoving, there are some 600 medieval examples known from England and Wales and they are useful indicators of the volume and nature of the coins in circulation at the time of their deposition (Allen, 2002, 2015). Their content is, however, a measure of the process of tesaurisation rather than evidence useful for interpreting the composition of the circulating coinage, the geographical distribution of medieval coins and the changing denominational profile through the period. Of the 95 medieval hoards of the period covered here discovered by metal detector users in recent years, it seems that only one has been excavated by an archaeologist (the Lenborough hoard, but see Gill, 2015). Very few of these recently metal detected groups have been fully published to monograph level, and due to this, it is not clear to what extent artefact hunting is leading to an increase in knowledge, apart from producing more examples (and more of a backlog) to study. Because of the way the law is constructed, a higher proportion of the hoards found and reported by metal detectorists since the passing of the Treasure Act of 1996 contain small numbers of coins. Most of them consist of from two to nine coins and are conventionally called "purse losses" or "purse spills", but very little is known about their context of deposition. The situation in the case of non-hoard finds of coins is however somewhat different. Recent studies such as those by Naismith (2013) and Richard Kelleher $(2011,2013,2017$ a) of single-finds of medieval coinage from England and Wales have revealed new information about patterns of deposition and the scale and form of the monetary economy.

The evidence from the PAS records of metal detecting finds seems to show that from the 1030 s and 1040 s, monetary circulation was stronger than had previously been suspected. There were substantial short-term fluctuations after the Norman Conquest related to various economic and monetary factors in the eleventh and twelfth centuries. The output of coinage increased after the ('Tealby') recoinage of 1158 , and especially after silver from the Erzgebirge region in southern Saxony started to be available (the issues of the short cross coinage in the reign of Henry II). The coin single-finds show that, even on rural sites, there was a great increase in coin loss in 1158-1247 that indicates a much greater degree of monetisation of the economy. This is why coins of Henry II, Richard and John are relatively frequent finds (and also on the antiquities market). With the long cross coins of Henry III and Edward I (12471307), such finds become even more frequently met. This is linked to population levels and access to coined money in the twelfth-thirteenth centuries. Initially, these coins occur as accidental losses mostly concentrated in the south and east of the country, with relatively few in Wales and other upland regions (though hoards may occur outside the regions where the coins were in circulation). Later on, the deposition of

${ }^{7}$ If only a half of them are sold in each cycle of ten day auctions, in a single year 37169 coins could be passing through this one internet sales site alone. 
coin single-finds suggests that their more frequent use spread further north and west. In this period, the areas where coin hoards and single-finds appear in greater densities coincide, though there is no correlation between the size or frequency of the former and the density of the latter. In fact the opposite is true, with large groups of coins being deposited in areas in which single losses were at low levels or absent.

The single-find record also contains some foreign coins. These include over 400 sterling/esterling continental imitations of English coins (from Flanders and the Netherlands) and 715 Scottish coins among the single-finds from the 1150s to the 1290s. In both cases this is a higher number than in hoards. Seen on the antiquities market and sold without provenance or collecting histories, the scale of use of these coins in England would be less well known.

While the main coin type in circulation throughout the period was the silver penny, by users cutting it into halves and quarters, units of exchange of smaller value could be created. The single-finds show that cut coins were frequently in circulation in the villages of rural England and Wales (Spencer, 2006; 2008, p. 128-129). We now know that their quantities increased with time, which is a feature not seen in the hoard evidence, where fractional coins rarely occur. In the period $1158-80$, the composition of the single-finds was $62 \%$ pennies, $27 \%$ cut halfpennies and $11 \%$ cut farthings (quarters). By $1247-1278$, pennies comprise only $38 \%$ of the recorded losses, cut halfpennies $45 \%$ and farthings $17 \%$. Understanding the nature of this process is a major factor in assessing how people were using coins in this phase. Edward I carried out a watershed coinage reform in 1279 that set the template for the style and structure of coinage in England for the next 200 years. One of the innovations was the issue of a round halfpenny and farthing (quarter penny) and a four penny coin (groat). The minting of small silver coins to replace the centuries-old practice of cutting pennies affected the ability of the consumer to modify the money at their disposal, but it effectively halted the use of small denomination coins. There are only low numbers of post-1279 halfpennies (639) and farthings (738) in the single-find record (and one cut post 1279 penny), which suggests that the recoinage coincided with a rise in prices generally.

The single-finds from rural contexts also show that other forms of modification of coins were also practiced. Edward I's large silver groats were not a success and are therefore rare (only 60 or so examples are known), and many of the known examples had been converted in medieval times into brooches. There are only four recorded on the PAS database, all of which had been modified. Another form of modification (Kelleher, 2012, p. 194-196; 2017b) is pennies that have been folded in half ("prayer pennies", fig. 3). These have occasionally been found in excavations, mainly on monastic sites, but there are 605 examples known from the activities of artefact hunters in all parts of England and Wales. There are a number of examples from the tenth century and the practice continued until 1500 and sporadically afterwards. In contemporary texts (Kelleher, 2012, p. 195), we read that the coin was bent over the injured or ill person and a vow offered to a saint, the coin was then supposed to be taken to a saint's shrine to be left there in fulfilment of the vow. A papal commission refers to this as "the English custom" (Finucane, 1977, p. 94-95). Since the written sources 


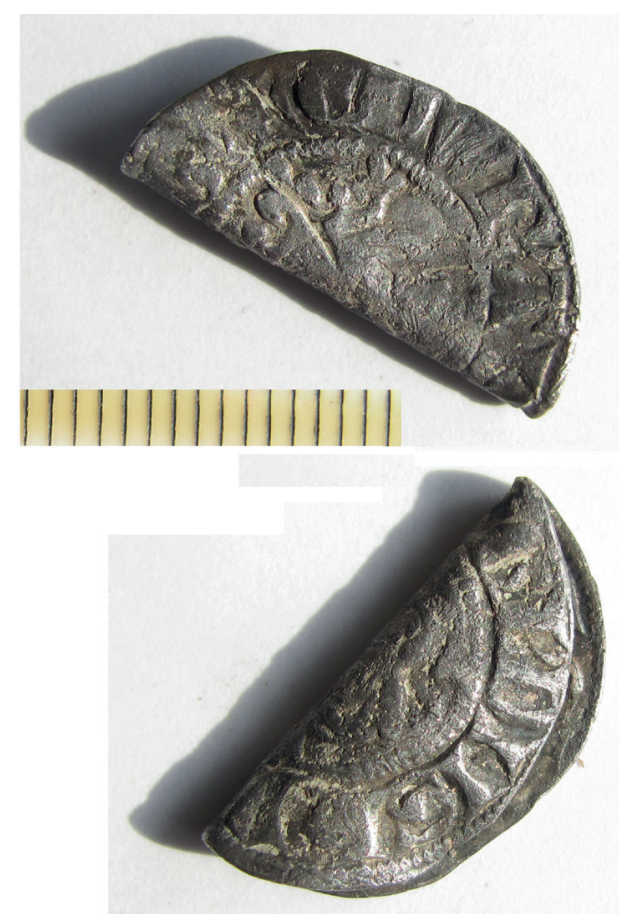

Fig. 3. 'Prayer penny', worn class 3 or 4 silver penny of Edward I (1280-9), deliberately folded over. NMS-A0A4B8, Norfolk Museums Service (Courtesy of the Portable Antiquities Scheme, scale in $\mathrm{mm}$ )

indicate that their purpose was to be deposited at a pilgrim shrine, it is not clear why these folded coins are found in the ploughsoil away from them. Perhaps some other processes connected with popular devotion are in evidence here, but while these are just loose coins brought for recording with no information of local context, associated material and evidence, we can just guess. Unfortunately the PAS record shows that before these artefacts reach the recorder, in order to make it more collectable, the finder has very frequently used a heat treatment to unbend the coin - sometimes damaging the object as well as altering its original folded form ${ }^{8}$.

\section{DISCUSSION}

In recent years, many vehement claims have been made about the benefits that can accrue for research through collaborating with collection-driven exploitation of the

\footnotetext{
${ }^{8}$ There are a number of videos showing how they do this on You Tube: https://youtu.be/swZZmZKtajg; https://youtu.be/uC_WcytrR9I; see also http://www.colchestertreasurehunting.co.uk/C/coinstraightening.htm
} 
archaeological record and documenting the artefacts deriving from this activity that are shown to archaeologists. This case study of the biggest and oldest database recording information deriving from this source suggests that the value of the material this produces for serious archaeological research on the medieval period is severely limited.

It is clear that the PAS database of England and Wales contains information on what collectors have collected rather than being a reflection of anything remotely like a systematic data acquisition policy, but neither is the selection a random one. It remains to be proven that, in the case of the medieval finds (over half of the material contained in the PAS database), these records can in fact be said to be making a particularly big contribution to the advancement of archaeological knowledge about the period, except in incidental matters.

Most of the finds contained in the PAS database are coins and, as shown above, it does seem that this material can provide some useful information about certain aspects of the medieval monetary economy. It must also be pointed out that coins are not only an easy subject to analyse by purely typological means, but are also addressed sources. This is why they are popular with collectors because they have intrinsic "meaning", unrelated to context of discovery; they have pictures and writing on them that can be related to the "kings and battles" history of school textbooks, indeed help to make it less abstract. It would be unusual if no information whatsoever could have been obtained from the study of some 40000 of them.

As for some of the other uses to which this material has been put, they often look more like attempts to make the PAS-recorded material "relevant". The plotting of finds around documented medieval sites by Oksanen, and Lewis and the characterisation of "accidental finds" by Geake really seem to have resulted in nothing more than the sort of trivialities that Flannery (1973) referred to as "Mickey Mouse Laws". In fact, in both examples, the observed features result from the confusion of patterns of collecting and archaeological evidence. Artefact collecting is no more archaeology than collecting costume Barbie dolls is ethnology.

The concentration on "big data" mapping also largely documents collecting and reporting patterns (see the example of the leash swivels). Robbins (2014), in what is intended as a manual for the use of PAS data in research, laboriously sets out the various constraints that hinder interpretation of the broad patterns, much of it concentrating on site formation processes. Yet, it is at the level of individual sites or segments of the archaeological record that there are large gaps in the detail of the recording. The loose objects are recorded without any observation or documentation of the context out of which individual items have been plucked. The database therefore records interference in the archaeological record and the removal of diagnostic and other artefacts at tens of thousands of places in England and Wales, but no way of recording their context of deposition in any detailed manner. This is not a remedy for "zero gain" (Deckers et al., 2018, p. 324), but simply destruction of archaeological information.

The use of information from artefact hunting has placed emphasis on big-data dot distribution maps, marking out broad cultural areas and zones. Research (e.g., Richards et al., 2009; Kershaw, 2014; Robbins, 2014) has focussed on what has (in Dutch 
palaeogeographic cartography, see Fokkens, 1998, p. 56-65) been called map formation processes. This approach however pays very little attention to the intermediate stage between sites and the big data, which is the history of landscapes (Cf. Kolen, Niekus, 2011). What the selective recording of artefact hunting finds has produced is a dispersion of "x-marks-the-spot" findspots scattered across a broad map, with nothing that links them to the local patterns of social dynamics their deposition represents. Without that, it is not true to say that the information gathered from artefact hunters (who were searching sites with another aim entirely in view) can ever fully "complement traditional archaeological survey and fieldwork" as claimed by their supporters.

Seen against the broader background, it may be observed that there is a methodological confusion and a certain amount of theoretical naivety represented by the object-centred writings of archaeologists able to contemplate collaboration with those engaged in destructive collection-driven exploitation of the archaeological record. A contributory factor is the comparative dearth of theoretical consideration in certain circles of the nature of archaeological sources, in comparison to Continental archaeology, well-reflected in the writings of Professor Stanisław Tabaczyński and in the Poznań School. This lack of methodological reflection favours a superficial, but fallacious, equation of a mere "lot of objects" with archaeological information.

It is difficult to escape the conviction that the claimed benefits of archaeologists intent on collaboration with artefact hunters are rather not so much for the discipline of archaeology, and certainly not the preservation of the archaeological record. The interests served are rather those of individual archaeologists who aspire to have ready access to (to get grant money to process) a mass of "raw data" gathered in one place for them to analyse and write about. This material, furthermore, is rendered easy for them to use, precisely because they are unencumbered with contextual detail (and, usefully, are available from anonymous third hand sources, to which can be ascribed any responsibility for problems with actual data quality).

In failing to address the scale of the damage being done, and as a result of their constant and uncritical praise of artefact hunting and the alleged benefits it has brought to the discipline, artefact-centred archaeologists intent on collaboration in the stripping of the archaeological record of artefacts like this are in fact promoting the practice. The claims that erosive and destructive collection driven exploitation of the archaeological record is a form of public engagement with archaeology and a form of "archaeology for all" would only be sustainable if it were conducted in a manner that is consistent with the methods and aims of archaeology. Otherwise it is simply pandering to the materialist ethos of the times, and the degree to which that is in any way socially beneficial is debatable.

\section{BIBLIOGRAPHY}

Allen, M.

2002 English coin hoards 1158-1544. British Numismatic Journal, 72, 24-84. 
2015 Coin Hoards in England and Wales c. 973-1544. In: J. Naylor, R. Bland (eds), Hoarding and Deposition of Metalwork from the Bronze Age to the 20th Century: a British Perspective (p. 147-165) (BAR British, Series 615). Oxford: Archaeopress.

Barford, P. M.

2016 Portable Antiquities Collectors and an Alter-Archaeology of Viking England. Acta Archaeologica Pultuskiensia, 5, 31-46.

2018 Revised Artefact Erosion Counter. Portable Antiquity Collecting and Heritage Issues blog, Sunday, 15 July 2018. Internet resource: https://paul-barford.blogspot.com/2018/07/a-revised-artefact-erosion-counter.html

2020 Green Saharas, Grey Markets: Commercial Exploitation of North African Prehistory, an Overview. Archaeologia Polona, 58, 311-338.

Beresford, M. W.

1954 The Lost Villages of England. London: Lutterworth Press.

Bland, R.

2005 A Pragmatic Approach to the Problem of Portable Antiquities: the Experience of England and Wales. Antiquity, 79(304), 440-447.

Boulton, $\mathrm{H}$.

2016 The British Museum Announces Most Successful Year Ever. Annual Review Launch 2016 British Museum press release 1st July 2016. Internet resource: https://enews.britishmuseum.org/pdf/annual-review-press-release.pdf

Champion, T. C.

1991 Medieval Archaeology and the Tyranny of the Historical Record. In: L. Alcock, D. Austin (eds), From the Baltic to the Black Sea, Studies in Medieval Archaeology (p. 79-95). London: Unwin Hyman.

Christiansen, $\mathrm{T}$.

2016 Recreational Metal Detecting and Archaeological Research: Critical Issues Concerning Danish Metal-detector Finds. In: J. Martens, M. Ravn (eds), Pløyejord som kontekst (p. 23-36). Kristiansand: Portal Forlag.

Coin Community Forum

2015 How Many Collectors Of Ancient Coins Are There? Coin Community Forum (thread 12/09/2015 to 12/11/2015). Internet resource: https://www.coincommunity.com/forum/ topic.asp?TOPIC_ID $=247375$

Deckers, P., Dobat, A., Ferguson, N., Heeren, S., Lewis, M., Thomas, S.

2018 The Complexities of Metal Detecting Policy and Practice: A Response to Samuel Hardy, 'Quantitative Analysis of Open-Source Data on Metal Detecting for Cultural Property' (Cogent Social Sciences, 3, 2017). Open Archaeology, 4, 322-333.

Dobat, A., Deckers, P., Heeren, S., Lewis, M., Thomas, S., Wessman, A.

2020 Towards a Cooperative Approach to Hobby Metal Detecting: The European Public Finds Recording Network (EPFRN) Vision Statement. European Journal of Archaeology, 23(2), 1-21.

Elia, R. J.

1997 Looting, Collecting, and the Destruction of Archaeological Resources. Nonrenewable Resources, 6, 85-98.

Finucane, R. C.

1977 Miracles and Pilgrimages, Popular Beliefs in Medieval England. London: Palgrave Macmillan.

Flanery, K. V.

1973 Archaeology with a Capital S. In: C. L. Redman (ed.), Research and Theory in Current Archaeology (p. 47-58). New York: Wiley.

Fokkens, H.

1998 Drowned Landscape: The Occupation of the Western Part of the Frisian-Drentian Plateau, $4400 B C-A D$ 500. Assen: Uitgeverij Van Gorcum. 
Geake, $\mathrm{H}$

2011 Accidental Losses, Plough-damaged Cemeteries and the Occasional Hoard: The Portable Antiquities Scheme and Early Anglo-Saxon Archaeology. In: S. Brookes, S. Harrington, A. Reynolds (eds), Studies in Early Anglo-Saxon Art and Archaeology: Papers in Honour of Martin G. Welch (p. 33-39) (BAR British, Series 527). Oxford: Archaeopress.

Gilchrist, R.

2009 Medieval Archaeology and Theory: a Disciplinary Leap of Faith. In: R. Gilchrist, A. Reynolds (eds), Reflections: 50 Years of Medieval Archaeology, 1957-2007 (p. 385-408). Leeds: Maney.

Gill, D.

2015 Damaging the Archaeological Record: The Lenborough Hoard. Journal of Art Crime, 13, $51-57$.

Greenlight Publishing 2020 Books. Publisher's catalogue: https://www.greenlightpublishing.com/ Hardy, S.

2017 Quantitative Analysis of Open-Source Data on Metal Detecting for Cultural Property. Cogent Social Sciences, 3(1), 1-49.

Hart, S. M., Chilton, E. S.

2014 Digging and Destruction: Artifact Collecting as Meaningful Social Practice. International Journal of Heritage Studies, 21(4), 318-335.

Jervis, B.

2017 Using Archaeological Objects. Living Standards and Material Culture in English Rural Households 1300-1600. Project blog, Posted on April 6, 2017: https://medievalobjects. wordpress.com/2017/04/06/using-archaeological-objects/

Jones, R.

2004 Signatures in the Soil: The Use of Pottery in Manure Scatters in the Identification of Medieval Arable Farming Regimes. Archaeological Journal, 161(1), 159-188.

2011 Elemental Theory in Everyday Practice: Food Disposal in the Later Medieval English Countryside. In: J. Klápšte, P. Sommer (eds), Food in the Medieval Rural Environment: Processing, Storage, Distribution of Food (p. 145-154). Turnhout: Brepols.

Karl, R.

2019 The 'Artefact Erosion Estimation' - Fallacy. Another Response to Papers by Samuel A. Hardy. Archäologische Denkmalpflege, 2, 73-143.

Kelleher, R. M.

2011 Coins in Context: Archaeology, Treasure and the Portable Antiquities Scheme. In: B. Cook (ed.), The British Museum and the Future of UK Numismatics: Proceedings of a Conference Held to Mark the 150th Anniversary of the British Museum 's Department of Coins and Medals (p. 18-24). London: British Museum Research Publication 183.

2012 The Re-use of Coins in Medieval England and Wales c. 1050-1550: an Introductory Survey. Yorkshire Numismatist, 4, 183-200.

2013 Coins, Monetisation and Re-use in Medieval England and Wales: New Interpretations Made Possible by the Portable Antiquities Scheme. Durham University, unpublished doctoral thesis. Available online: http://ethos.bl.uk/OrderDetails.do?did=618\&amp;uin=uk. bl.ethos. 571965

2017a The Monetisation of Medieval England and Wales, New Interpretations from Single Finds (c.1150 - c.1300). In: M. C. Caltabiano, B. Carroccio, D. Castrizio, M. Puglisi, G. Salamone (eds), XV International Numismatic Congress Taormina 2015 Proceedings, t. 2 (p. 1133-1137). Rome: Arbor Sapientiae Editore.

2017b Pilgrims, Pennies and the Ploughzone, Folded Coins in Medieval Britain. In: N. M. Burström, G. T. Ingvardson (eds), Divina Moneta: Coins in Religion and Ritual (p. 68). Abingdon - New York: Routledge. 
Kennedy, M.

2007 'Unsung Heroes of Heritage' Extolled for Unearthing Hoard of Treasure: Gold and Silver Jewellery Among Surge in Finds by Metal Detector Sleuths. The Guardian, Thu 18 Jan 2007.

Kershaw, J.

2013 Viking Identities: Scandinavian Jewellery in England. Oxford: Oxford University Press.

Kolen, J. C. A., Niekus, M.

2011 Van cultureel streekdiagram tot landschapsbiografie. Een overzicht van vijftig jaar landschapsarcheologie in Drenthe. In: M. J. L. Th. Niekus, S. van der Zee, T. Looijenga, F. Kiestra (eds), Gevormd en omgevormd landschap (p. 132-144). Assen: Drents Prehistorische Vereniging.

Leahy, K., Lewis, M.

2018 Finds Identified: an Illustrated Guide to Metal-detecting and Archaeological Finds. Coggeshall: Greenlight Publishing.

Lewis, C.

2007 New Avenues for the Investigation of Currently Occupied Medieval Rural Settlement Preliminary Observations from the Higher Education Field Academy. Medieval Archaeology, 51, 131-161.

Lewis, M.

201850 Medieval Finds from the Portable Antiquities Scheme. Stroud: Amberley Publishing.

2016 A Damaged Past: the Effects of Historical Artefact Collecting on the Stone Artefact Record. Victoria Excavations, Surveys and Heritage Management in Victoria, 5, $47-50$.

Loveluck, C., More, A., Spaulding, N., Clifford, H., Handley, M., Hartman, L., Korotkikh, E., Kurbatov, A., Mayewski, P., Sneed, S., McCormick, M.

2020 Alpine Ice and the Annual Political Economy of the Angevin Empire, from the Death of Thomas Becket to Magna Carta, c. AD 1170-1216. Antiquity, 94(374), 473-490.

Naismith, R.

2013 The English Monetary Economy c. 973-1100: the Contribution of Single finds. Economic History Review (new series), 66, 198-225.

Oksanen, E., Lewis, M.

2015 Medieval Markets and PAS Data. Medieval Settlement Research, 30, 54-59.

Oksanen, E., Lewis, M.

2016 Exploring the Commercial Landscape of Medieval Saltfleetby and Skidbrooke (Lincs.) through PAS data. Medieval Archaeology, 60, 14-17.

Pitblado, B.

2014 An Argument for Ethical, Proactive, Archaeologist-artifact Collector Collaboration. American Antiquity, 79(3), 385-400.

Pitblado, B., Shott, M. J.

2015 The Present and Future of Archaeologist-collector Collaboration. The SAA Archaeological Record, 15(5), 36-39.

Pesez, J.-M.

1990 Archéologie et histoire médiévales. Heresis, 2, 7-24.

Portable Antiquities Scheme

1998-2020 (database) Internet resource: https://finds.org.uk/database

Portable Antiquities Scheme

2003-2020 Research Based on Scheme data. Portable Antiquities Scheme. Internet resource: www. finds.org.uk/research

Reeves, M.

2015 Sleeping with the Enemy: Metal Detecting hobbyists and Archaeologists. Advances in Archaeological Practice, 3(3), 263-274. 
Richards, J. D., Naylor, J., Holas-Clark, C.

2009 Anglo-Saxon Landscape and Economy: Using Portable Antiquities to Study Anglo-Saxon and Viking Age England. Internet Archaeology, 25. Internet resource: http://intarch.ac.uk/ journal/issue25/richards_index.html

Robbins, $\mathrm{K}$.

2014 Portable Antiquities Scheme: A Guide for Researchers. London: British Museum. Internet resource: https://finds.org.uk/documents/guideforresearchers.pdf

Spencer, P. D.

2006 Cut Halves and Quarters: Statistics. The Searcher, July 2006, 45-47.

2008 The Construction of Histories: Numismatics and Metal Detecting. In: S. Thomas, P. Stone (eds), Metal Detecting and Archaeology (p. 125-136). Woodbridge - Rochester: Boydell Press.

Tabaczyński, S.

1987 Archeologia średniowieczna. Problemy. źródta, metody, cele badawcze. Wrocław: Ossolineum.

Temińo, I. R., Valdés, A. R.

2015 Fighting Against the Archaeological Looting and the Illicit Trade of antiquities in Spain. International Journal of Cultural Property, 22(1), 111-130.

Thomas, $\mathrm{S}$.

2008 Introduction. In: S. Thomas, P. Stone (eds), Metal Detecting and Archaeology (p. 1-11). Woodbridge - Rochester: Boydell Press.

2016 The Future of Studying Hobbyist Metal Detecting in Europe: A Call for a Transnational Approach. Open Archaeology, 2, 140-149.

Thomas, S., Stone, P. (eds)

2008 Metal Detecting and Archaeology. Woodbridge - Rochester: Boydell Press.

Treasure Act

1996 An Act to Abolish Treasure Trove and to Make Fresh Provision in Relation to Treasure. UK Public General Acts 1996, c. 24.

Vernet, R., Le Quellec, J.-L.

2017 Recension de: Eckhard Klenkler, Robert Dreikluft, Mark Milburn and Z. Jiang 2016, Sahara, Material Culture of Early Communities. Les Cahiers de l'l'Association des Amis de l'Art Rupestre Saharien, 19, 295-297.

Winkley, F.

2016 The Phenomenology of Metal Detecting: Insights From a Unique Type of Landscape Experience. Papers From the Institute of Archaeology, 25(2), Art. 13. Internet resource: http://doi.org/10.5334/pia.496

Worrell, S., Egan, G., Naylor, J., Leahy, K., Lewis, M. (eds)

2010 A Decade of Discovery: Proceedings of the Portable Antiquities Scheme Conference 2007

(BAR British, Series 520). Oxford: Archaeopress.

\title{
ZBIERANIE ARTEFAKTÓW: TWORZENIE CZY NISZCZENIE ŹRÓDŁA ARCHEOLOGICZNEGO?
}

\author{
Streszczenie
}

Praktyka szukania i zbierania artefaktów archeologicznych i historycznych jest potępiana w większej części świata, ponieważ jest postrzegana jako niszcząca dla źródła archeologicznego. Pogląd ten nie jest powszechnie akceptowany. W niektórych krajach hobbystyczne zbieranie arte- 
faktów z wykorzystaniem wykrywaczy metali, w celu ich zdobycia, jest postrzegane jako środek umożliwiający społeczeństwu zaangażowanie się w poznawanie przeszłości. Ten pogląd popierają archeolodzy, którzy mają nadzieję uzyskać w ten sposób dostęp do zabytków odkrytych przez poszukiwaczy w celu udokumentowania artefaktów i wykorzystania tych „danych” w swoich badaniach.

Argumenty, których archeolodzy ci używają do obrony swoich poglądów, są analizowane w tym artykule na podstawie przypadku materiału wczesnośredniowiecznego (artefakty i monety) znalezionego przez detektorystów w Anglii i Walii i udokumentowanego przez archeologów. Wykazano, że niereprezentatywne, zdekontekstualizowane przedmioty, które gromadzą poszukiwacze, nie mogą być wykorzystane w badaniach jako pełnowartościowe dane archeologiczne. Obecny „,powrót do rzeczy" nie może zachęcać do zastąpienia metodycznego badania pozostałości archeologicznych w ich kontekście. 